\title{
Well-Differentiated Pediatric Glial Neoplasms with Features of Oligodendroglioma, Angiocentric Glioma and Dysembryoplastic Neuroepithelial Tumors: A Morphological Diagnostic Challenge
}

\author{
Oligodendrogliom, Anjiosentrik Gliom ve Disembriyoplastik \\ Nöroepitelyal Tümör Özellikleri Taşıyan İyi Diferansiye Pediatrik Glial \\ Tümörler: Morfolojik Bir Tanısal Sorun
}

\author{
Hande KESER ${ }^{1}$, Michael BARNES ${ }^{2}$, Gregory MOES ${ }^{3}$, Han Sung LEE², Tarık TiHAN² \\ Department of Pathology, ${ }^{1}$ Cumhuriyet University, Faculty of Medicine, SIVAS, TURKEY, ${ }^{2}$ University of California, SAN FRANCISCO, USA, \\ ${ }^{3}$ Kaiser Permanente Oakland Medical Center, OAKLAND, USA
}

\begin{abstract}
Objective: Oligodendrogliomas are rare in the pediatric population, and most oligodendroglioma-like tumors in this age group may belong to other entities. In addition, accurate diagnosis and grading of such lesions using criteria developed for adult oligodendrogliomas prove difficult, and often controversial.
\end{abstract}

Material and Method: During a study of tumors previously diagnosed as pediatric oligodendroglioma, we identified four tumors displayed features of that resembled oligodendroglioma, angiocentric glioma and dysembryoplastic neuroepithelial tumor but could not be classified as either one of these entities. Ther clinical, histological and immunohistochemical features of these cases were investigated in this study.

Results: Two male (both 9 years old) and two female (ages 4 years and 20 months) patients presented with new onset of seizures. All patients were treated surgically, and two required reoperation. Histologically, the tumors were well-differentiated glial neoplasms with focal angiocentric pattern, delicate vascularity, diffuse growth, infiltrative margins, cortical nodules, focal myxoid areas, and leptomeningeal extension. Immunohistochemical studies showed diffuse nuclear positivity with Olig-2 and GFAP antibodies, whereas staining with neuronal markers, EMA, p53, and IDH1 were negative. Fluorescent in-situ hybridization analysis demonstrated intact $1 \mathrm{p} / 19 \mathrm{q}$ in all tumors, and there was no ultrastructural evidence of ependymal differentiation. All patients were alive with disease with a mean follow-up of 112 months.

Conclusion: These four cases illustrate the morphological diversity of well-differentiated, oligodendroglioma-like glial neoplasms and the uncertainty in their classification among pediatric tumors.

Key Words: Glioma, Oligodendroglioma, Pediatric brain neoplasms

(Turk Patoloji Derg 2014, 30:23-29)

Received : 15.08.2013 Accepted : 22.09.2013
ÖZ

Amaç: Oligodendrogliom çocukluk çağında çok ender görülen bir tümördür ve bu yaş grubunda oligodendrogliom izlenimi veren tümörler çoğunlukla diğer glial tümör gruplarına aittir. Ayrıca bu tümörlerin kesin tanısı ve özellikle erişkin oligodendrogliomlar için oluşturulmuş kriterler kullanılarak derecelendirilmesi ciddi zorluklara ve tartışmalara neden olmaktadır. Pediatrik oligodendrogliom olarak tanı almış bir dizi tümörün yeniden incelenmesi sırasında bu tanıya uymayan ve kesin olarak sinıflandırılamayan dört olgu bu yazının konusunu oluşturmaktadır.

Gereç ve Yöntem: Oligodendrogliom çalışmasına dahil edilmeyen bu dört tümör morfolojik olarak oligodendrogliom, anjiosentrik gliom ve disembriyoblastik nöroepitelyal tümör özellikleri içermekle birlikte bu kategorilerden hiçbirine uyumluluk göstermemektedir. $\mathrm{Bu}$ çalışmada, olguların klinik, histolojik ve immünohistokimyasal özellikleri araştırılmıștır.

Bulgular: İki erkek (her ikisi de 9 yaşında) ve iki kız çocuk hasta (4 yaşında ve 20 aylık) yeni gelişen epilepsi nöbetleri ile kliniğe başvurdu. Tüm olgulara cerrahi tedavi uygulandı ve iki hastada tekrar cerrahi girişim gerekti. Histolojik olarak bütün tümörlerde diffüz beyin dokusu infiltrasyonu, fokal anjiosentrik yapılanma, kortikal nodüller, fokal miksoid alanlar ve leptomeningial yayılım saptandı. İmmünhistokimyasal çalışmalar sonucu Olig-2 ve GFAP antikorları ile pozitif boyanma, EMA, p53, IDH-1 ve nöronal belirteçler ile negative boyanma görüldü. FISH yöntemi ile tüm tümörlerde $1 \mathrm{p} / 19 \mathrm{q}$ kaybının bulunmadığı, elektron mikroskopik incelemede ise ependimal farklılaşmayı gösteren bir bulgu olmadığı saptandı. Dört hasta, ortalama takip süresi olan 112 ay sonunda yaşamlarını sürdürmekteydiler.

Sonuç: $\mathrm{Bu}$ dört olgu iyi diferansiye ve oligodendrogliom benzeri pediyatrik gliyal tümörlerin çeşitliliğini ve tanılarında karşılaşılan sorunları irdelemektedir.

Anahtar Sözcükler: Gliom, Oligodendrogliom, Pediyatrik beyin tümörleri

Correspondence: Tarık TIHHAN

University of California, San Francisco, Department of Pathology,

SAN FRANCISCO, USA

E-mail: tarik.tihan@ucsf.edu Phone: +1 4154765236 


\section{INTRODUCTION}

Classification of some pediatric primary central nervous system tumors can be challenging on the basis of routine histology and immunohistochemistry. Advances in the genetic and molecular characterization of these pediatric tumors may help establish unique entities, and allow reclassification of pediatric tumors previously considered in a given category.

Oligodendrogliomas (OD) are rare tumors, comprising less than $5 \%$ of primary intracranial tumors in adults (1), and perhaps less than $2 \%$ among childhood tumors (2). Typical adult OD is characterized by a markedly monomorphous, diffusely infiltrative neoplasm with corticocentricity and a slowly progressive course. The diagnosis is often aided by the presence of secondary histological structures of Scherer, combined losses in chromosome $1 \mathrm{p}$ and $19 \mathrm{q}$, and mutations in the either IDH-1 or the IDH-2 gene.

While OD is considered a tumor of adults, rare reports identify tumors with similar features in the pediatric population. Many studies on OD included patients younger than 15 years, but only a few studies analyzed pediatric OD exclusively. Such studies present some evidence that the biology of these tumors may be different from their adult counterparts. In a study of 21 children with oligodendroglial tumors, Raghavan et al. found only three cases with combined losses of chromosome $1 p$ and $19 q$ (2). Another study demonstrated a much higher survival probability of pediatric oligodendrogliomas compared to adults (3). Thus, pediatric ODs reported to date seem to lack the typical molecular and clinical features of adult ODs, and the distinction from other well-differentiated tumors such as dysembryoplastic neuroepithelial tumor (DNT) may be extremely difficult (4).

Angiocentric gliomas are rare tumors with fewer than 50 cases reported in the literature (5). The tumors typically present in children and young adults with a history of refractory seizures, and a slow-growing cerebral hemispheric mass $(6,7)$. Histologically, the tumors have a typical angiocentric growth pattern in an infiltrative manner, and ultrastructurally show ependymal differentiation (8). Cortical dysplasia has been found in association with these tumors, suggesting a developmental basis to their origin (9). Prognostically, patients have a stable clinical course with complete surgical resection probably leading to cure, while residual tumor may remain stable for long periods $(7,10)$. However, recent observations suggest that rare examples may behave more aggressively (11).
DNTs are pseudo-hamartomatous lesions typically seen in children and young adults, and associated with complex partial seizures. These tumors are overwhelmingly seen in the cerebral cortex with a predilection for the temporal lobe. DNTs have a good prognosis and are typically cured by resection with the overwhelming majority remaining seizure-free postoperatively. Histologically, the tumors form patterned mucin-rich nodules containing OD-like cells and "floating" neurons. Two distinct forms, the simple and complex, are recognized by the WHO classification. A third category has been suggested by some authors and tumors in this category have been termed "non-specific DNT", but this concept has not found widespread acceptance (12).

A growing number of tumors are being diagnosed as having an OD-like component, a finding that demands caution in interpretation (13). There is still uncertainty about whether such tumors represent divergent glial differentiation within a single population of neoplastic cells or coexistence of two distinct biological processes; the so-called "collision" tumors. Naturally, the former suggestion implies a histological pattern without a distinct biological significance. Alternatively, such a pattern may represent a variant of an entity, or a distinct entity entirely. While pathological analysis carries much credibility in the recognition of new variants, it may not provide a clear answer in all cases.

This study presents four cases that do not fit into classical definitions of the WHO recognized entities within our differential diagnosis. All tumors demonstrated features that can be seen in ODs, angiocentric gliomas, and DNTs. Through the study of these four cases, we aim to highlight the nosological problems prevalent in the literature on this diverse group of pediatric neoplasms.

\section{MATERIAL and METHODS}

Four cases were identified as unusual outliers during a multi-institutional study of pediatric ODs at the University of California, San Francisco Medical Center. These four cases were excluded from the original study because they did not fulfill the diagnostic criteria used to include the cases as OD. All four patients were originally diagnosed as OD between 1998 and 2007. Clinical and radiological information were collected from available patient files after obtaining appropriate IRB approval. All available paraffin blocks and glass slides were retrieved, and morphological features were recorded. Serial sections from each block were used for immunohistochemical staining and fluorescent in-situ hybridization. Immunohistochemical analyses were performed at the UCSF Department of 
Pathology Histology Laboratory using appropriate positive and negative controls. (Chromogranin, Synaptophysin [DAKO, 1:80], Ki-67 [DAKO, 1:600], p53 [Novocastra, 1:200], GFAP [DAKO, 1:400], NeuN [Chemicon, 1;500], IDH-1 [HistoBiotech (DiaNova), 1:100]). Analysis for $1 \mathrm{p} / 19 \mathrm{q}$ deletion was performed and as previously described using commercially available probes (VYSIS) $(3,4)$. Both $1 p$ and $19 \mathrm{q}$ probes are located within the minimally deleted regions in ODs. Probes for $1 \mathrm{q}$ and $19 \mathrm{p}$ were used as internal controls. Normal brain revealed a ratio of $>0.9$ for both probe pairs (1p-1q; 19p-19q).

\section{RESULTS}

\section{Clinical Features}

Case 1: The patient was a nine year-old boy who developed seizures at the age of 5 that began in the right arm, and secondarily became generalized. Initial physical examination did not reveal any focal neurological signs or symptoms. His past medical history was significant for migraine and obsessive compulsive disorder. Preoperative MRI showed a $3 \times 2 \mathrm{~cm}$. non-enhancing, wellcircumscribed mass with a central cystic component close to the motor strip in the left frontoparietal cortex. There was mild surrounding edema, but no significant midline shift. He was taken to the operating room, and a relatively avascular, soft and gritty tumor without clear-cut borders was resected. The extent of surgery was not clear due to indistinct borders of the neoplasm intraoperatively. The initial diagnosis was OD. Post-operative MRI showed residual T2 hyperintensity at the resection site, possibly representing residual tumor. Postoperative course was complicated by a bone flap infection and revision of his cranioplasty. The patient underwent six weeks of external beam radiation therapy. The patient experienced rightsided sensory auras immediately following therapy, but his symptoms resolved within two years, and he discontinued anticonvulsant medication. Five years later, at the age of 14 , he presented again with recurrent generalized seizures, sensory symptoms, and a constant bilateral headache. Repeat imaging showed elevated T2 signal in the left parietal area, unchanged from previous studies. The patient was put back on anticonvulsant medications. He is currently seizure-free without evidence of recurrence 14 years after initial surgery.

Case 2: The patient was a nine-year-old boy who presented with a one-week history of seizures that became secondarily generalized. A left parietal lobe tumor was resected and diagnosed as OD. The patient did well for the next five years, when his seizures reemerged, primarily beginning at the right lower extremity. The seizures continued to increase over the next two years despite therapeutic levels of anticonvulsants. At this time, MRI studies showed a $3 \times 1.5 \mathrm{~cm}$. area of new enhancement at the resection site, suggestive of recurrent neoplasm. The enhancement was not associated with mass effect or edema. The patient underwent a second craniotomy with electrocorticography and resection of the epileptogenic area. The resected tumor was again diagnosed as OD, but no grade was given. Patient had postoperative complications including pseudomonas meningitis and wound infection. His seizures were controlled with anticonvulsant medications. A followup MRI showed increase in T2 signal hyperintensity that became stable. The patient is alive with disease 10 years after initial surgery.

Case 3: The patient was a 20 month-old girl who presented with a two-week history of secondarily generalized seizures. Initial physical examination was unremarkable, but an MRI study showed an ill-defined area of increased T2 signal with evidence of enhancement in the right medial temporal lobe. The lesion reportedly increased in size between two imaging studies over several weeks. She underwent surgical debulking of the tumor few months after her first seizure. Intraoperatively, a poorly defined, pink-gray tumor was recognized, but could not be completely excised. The tumor was diagnosed as a well-differentiated glioneuronal neoplasm with some features of a DNT. No adjuvant therapy was given. Four years after initial surgery, the patient is seizure-free on anticonvulsant medication.

Case 4: The patient was a four year-old girl who was brought to the clinic following a single seizure episode. Initial neurological examination was unremarkable. MRI studies showed a $3 \times 2 \mathrm{~cm}$. partially calcified mass in the left medial temporal lobe with mild edema but no mass effect. The epileptogenic focus was localized to the left temporal lobe on EEG. She underwent partial tumor resection, and the neoplasm was diagnosed as a "low-grade OD with small foci of low-grade astrocytoma". The patient was seizure-free for the next two years, after which time the seizures reemerged. MRI examination at the time was interpreted as tumor recurrence, and she underwent a second resection followed by external beam radiation. One month after external radiation, she was hospitalized with disseminated varicella. She remained seizure-free for the next 8 years. She is currently alive 14 years after initial presentation, but information on her seizure status and tumor recurrence is not available beyond the first 10 years of her disease.

Radiologic Findings: All tumors were relatively wellcircumscribed intra axial lesions with hyperintense signals on T2-weighted and FLAIR sequences. None of the 


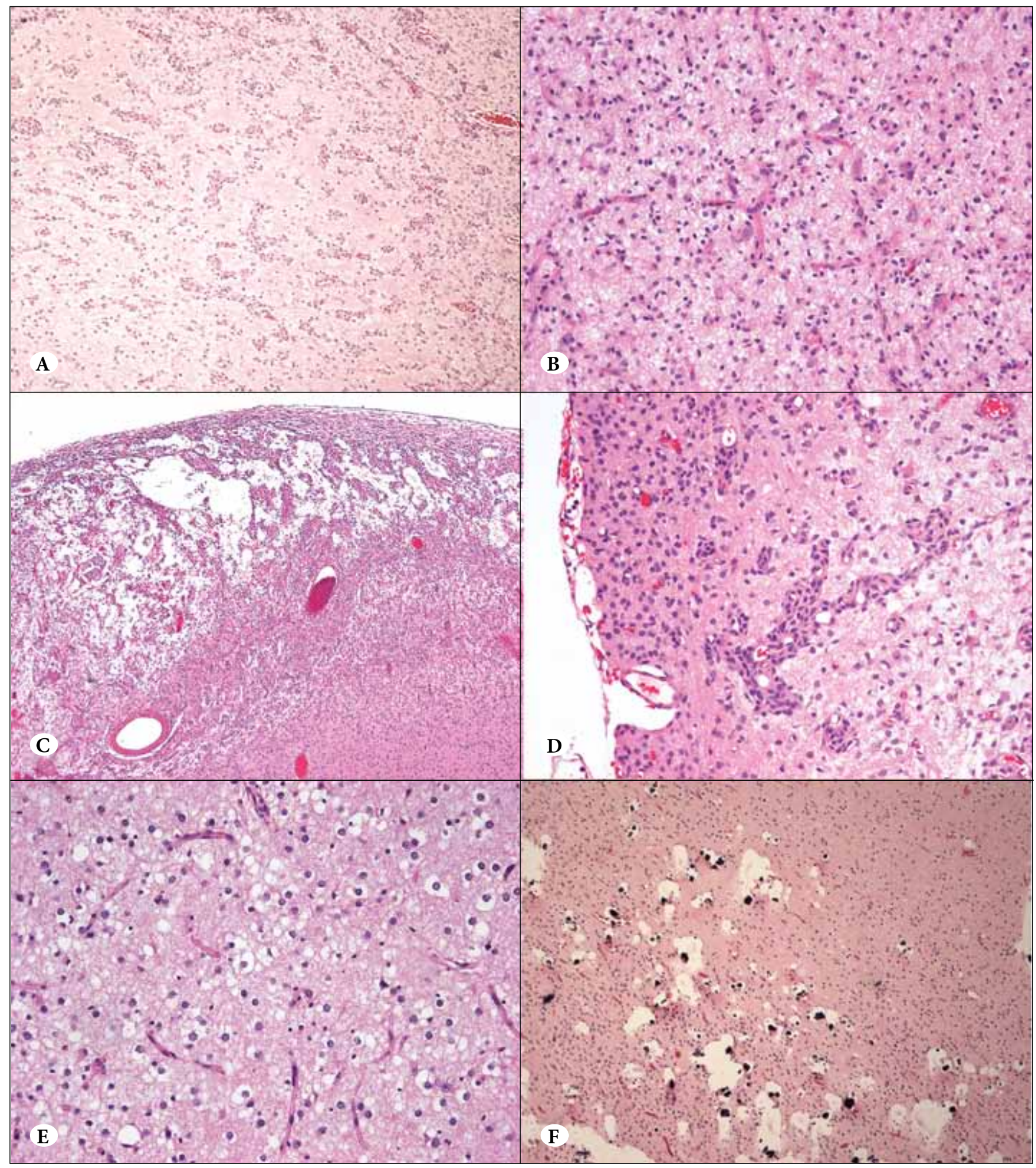

Figure 1: Diversity of tumors showing hybrid features. A) Low power magnification of tumors with predominantly an angiocentric pattern, reminiscent of angiocentric glioma (H\&E, x40). B) Oligodendroglioma-like areas with typical chicken-wire vascularity and round monomorphous cells with scattered haloes (H\&E, x200). C) The striking leptomeningeal spread of tumor cells with subpial growth pattern (H\&E, x40). D) Subpial growth of tumors cells along with angiocentric arrangement akin to angiocentric gliomas. E) Fried-egg like perinuclear haloes and an infiltrative pattern in the white matter (H\&E, x400). F) Microcalcifications predominantly seen in the cortex involved by tumor cells (H\&E, x40). 
lesions demonstrated mass effect or peritumoral edema. Two cases demonstrated a cystic component and two had radiologically detectable calcifications. All tumors involved the cortex and underlying white matter without obvious nodular intracortical appearance that would be typical of DNT. None of the tumors showed enhancement upon gadolinium administration.

Histological Findings: All tumors were removed in a piecemeal fashion, making the interpretation of macroscopic features quite difficult. Microscopically, all tumors were composed of monomorphous population of well-differentiated neuroepithelial cells infiltrating the cortex and the white matter with focal angiocentric pattern (Figure 1A), and on a background of delicate, "chickenwire" type vasculature (Figure 1B). There were areas of leptomeningeal spread as well as subpial clustering of tumor cells (Figure 1C,D). Tumor cells had round, regular, and monomorphic nuclei with sharply defined nuclear membranes and perinuclear haloes, reminiscent of OD (Figure1E). Some tumor cells were bipolar with elongated nuclei, fine, stippled chromatin, and inconspicuous nucleoli. In some of the cortical sections, satellitosis of tumor cells was also observed. Focal myxoid areas were present along with rare nodular arrangements within the cortex and white matter. Necrosis or vascular proliferation were not observed, and mitoses were sparse or absent. All cases exhibited a population of cells resembling oligodendroglial cells with rounded nuclei, scant cytoplasm, and focal pericellular clearing. Calcifications were present in two of the tumors (Figure 1F). Adjacent or associated cortical dysplasia was

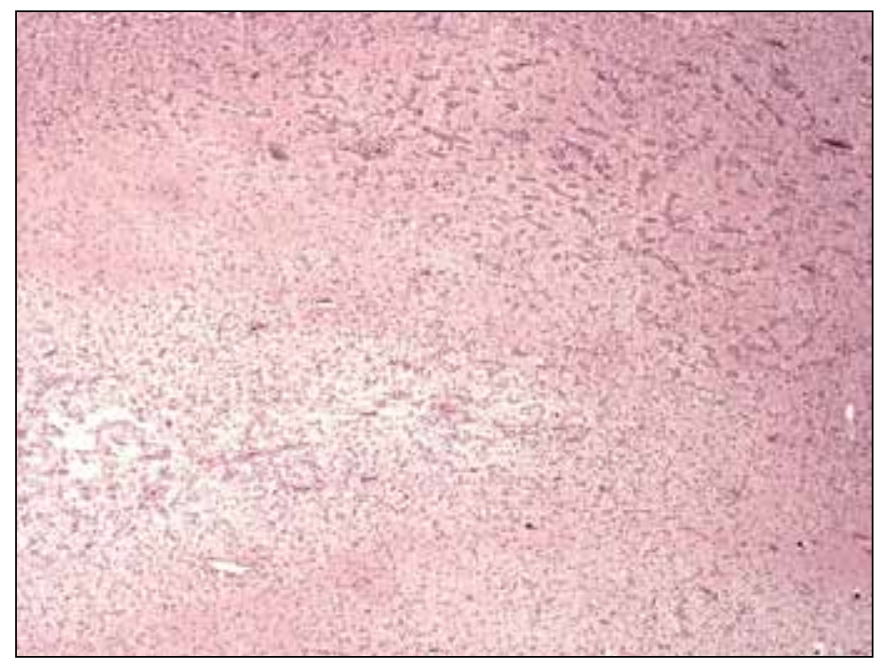

Figure 2: Low power magnification of typical microscopic appearance of tumors reported in this manuscript. The tumors often demonstrated regions reminiscent of DNT along with areas typical of angiocentric glioma (H\&E, x20). not observed in any of the samples. In many foci, the low power appearance of the tumor had the combined typical features of angiocentric glioma and DNT (Figure 2).

Immunohistochemistry and FISH: Representative sections from all tumors were stained with a panel of antibodies as listed in materials and methods. The tumors were strongly and diffusely positive with Olig-2, and to a lesser extent with GFAP (Figure 3A). Neuronal markers Neu-N, synaptophysin, and neurofilament proteins were negative in tumor cells, and highlighted the underlying or infiltrated neuropil (Figure 3B). The tumors were also negative for IDH-1, EMA, and p53 protein. The proliferation index as assessed by Ki-67 staining ranged from $1 \%$ to $3 \%$.
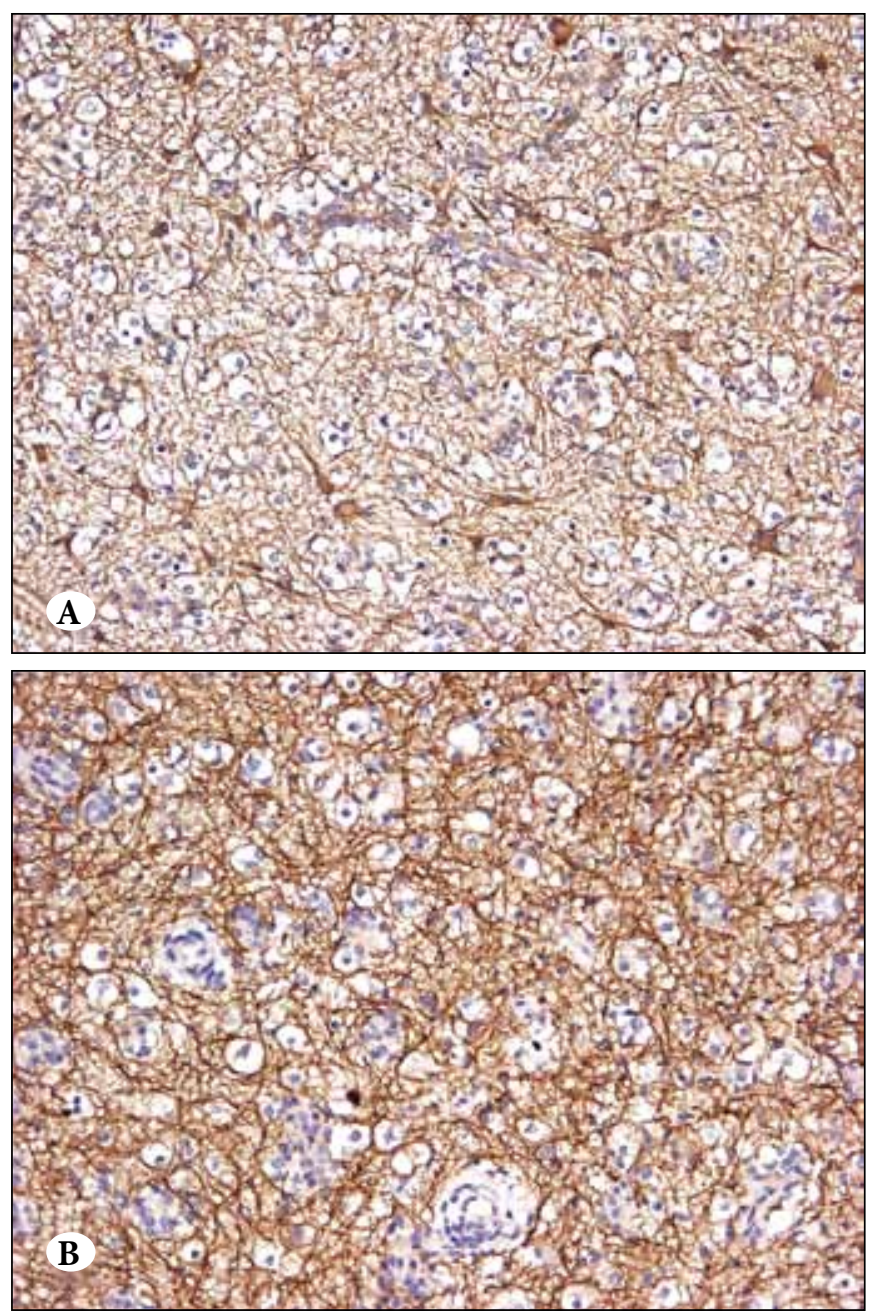

Figure 3: Immunohistochemical staining patterns of tumors with hybrid features. A) GFAP staining showing strong diffuse positivity (Immunohistochemistry, x400). B) Neurofilament protein staining demonstrating the positivity of the underlying neuropil. None of the tumor cells demonstrated neuronal marker staining (Immunohistochemistry, x400). 
FISH studies for $1 \mathrm{p} 19 \mathrm{q}$ co-deletion revealed no recognizable alterations in chromosomes 1 or 19.

Ultrastructural Analysis: Samples from two tumors were available for ultrastructural analysis. Both specimens were obtained fresh, and fixed in glutaraldehyde for electron microscopic analysis. Thick sections revealed tumor samples representative of the angiocentric and infiltrative patterns seen on H\&E. Both tumors were moderately rich in intermediate filaments. One tumor demonstrated increased rough endoplasmic reticulum. Exceptionally, there was a poorly formed, desmosome-like cell junction, but there was no clear evidence of ependymal or neuronal differentiation. The overall impression for both cases was more of a mature glial cell population with stunted cellular processes, and rich in intermediate filaments.

\section{DISCUSSION}

The four tumors presented in this report pose a diagnostic dilemma and a challenge in both typing and grading. Our main differential diagnosis included $\mathrm{OD}$, angiocentric glioma and DNT, but none of these options entirely covered the features seen in these tumors.

All tumors were located in the cortex and white matter in a diffusely infiltrative fashion, reminiscent of OD. Radiological features were also consistent with this impression. The presence of intracortical nodules, angiocentric arrangement of tumor cells, absence of IDH-1 mutation, and lack of $1 p 19 q$ alterations are not consistent with the diagnosis of OD. The non-progressive nature of these tumors without true progression also argues against this possibility. The oligodendroglial appearance is one of the many patterns we have observed in these tumors, but we do not suggest that these tumors have oligodendroglial components. The strongest argument against this possibility remains the recognition of histological patterns atypical of OD. Therefore, we could not classify these tumors as OD.

Angiocentric gliomas are WHO Grade I supratentorial tumors most commonly seen in children and young adults, associated with seizures and epilepsy. They present as slow growing, cerebral hemispheric mass lesions. Histopathologically, they exhibit a distinct angicentric growth pattern of uniform mature appearing glial cells with uniform, speckled chromatin and limited cytoplasm. Mitoses, necrosis vascular proliferation, and meningeal extension are generally absent. These tumors have been suggested to demonstrate a vague ependymal quality, and show evidence of ependymal differentiation both immunohistochemically and ultrastructurally. Absence of ependymal differentiation along with histological features (such as intracortical nodules) makes this diagnostic possibility unlikely for our cases.

All tumors also showed characteristics that could be interpreted as DNT. Clinical presentation, location, radiological features, and histological features (myxoid background, intracortical nodules, "floating" neurons, and low grade elements) are all consistent with this diagnosis. However, the entire histological picture is not consistent with this diagnosis, either. In all cases, tumor cells freely infiltrated the cortex and the white matter creating angiocentric pattern, subpial clustering and leptomeningeal spread. We were not able to find associated cortical dysplastic elements. While it is possible that some may recognize these features as the so-called nonspecific forms of DNT, we believe that the tumors do not entirely fit this category either.

In summary, our data on these four interesting low-grade neuroepithelial neoplasm prevent us to conclusively place them into one of the three categories; OD, angiocentric glioma or DNT. The diagnoses, or more appropriately, the categorization of these four cases were suggested based on their unique but perplexing histological features, and the impression was supported by the absence of typical mutations and genetic aberration of ODs. Immunohistochemical studies were not helpful in positively identifying these tumors as one of the well-recognized entities in the current WHO classification. All these tumors can be considered indolent lesions, but the choice of the tumor type would result in either WHO grade I (angiocentric glioma or DNT) or WHO grade II (OD) designation. However, the limited number of cases and a moderate length of follow-up do not allow us to make a grade designation with certainty. We believe that pediatric tumors within this morphological spectrum are best managed conservatively, especially if a gross total or near gross total resection could be achieved on initial surgery.

Recent studies on the genetic aspects of pediatric glial neoplasms are promising, and it is quite possible that the near future will bring additional genetic markers that can conclusively classify such tumors in specific categories (13). Until then, the typing and grading of these four tumors become problematic. Practically, the clinicians treating these tumors will be quite dissatisfied with this vague diagnosis and tumor grade that can be either WHO grade I or II. However, we do not feel that we have enough evidence to suggest these tumors as a distinct entity or a variant of a specific entity. The best solution appears to be a cautious approach and direct communication (with detailed discussion of the pathological and clinical features) 
that should result in a personalized management of each patient.

While the authors of this study have their own bias as to the final pathological diagnosis, it is critically important to recognize that there is insufficient scientific evidence to place tumors such as the cases presented here into precise diagnostic category and grade. We hope that the rapidly expanding field of molecular pathology of central nervous system tumors will allow us to be more specific without being subjective and arbitrary in the very near future (14).

\section{REFERENCES}

1. Dolecek TA, Propp JM, Stroup NE, Kruchko C. CBTRUS statistical report: Primary brain and central nervous system tumors diagnosed in the United States in 2005-2009. Neuro Oncol. 2012; Suppl 5:v1-49.

2. Raghavan R, Balani J, Perry A, Margraf L, Vono MB, Cai DX, Wyatt RE, Rushing EJ, Bowers DC, Hynan LS, White CL 3rd. Pediatric oligodendrogliomas: A study of molecular alterations on $1 \mathrm{p}$ and $19 \mathrm{q}$ using fluorescence in situ hybridization. J Neuropathol Exp Neurol. 2003; 62:530-7.

3. McDonald WC, Nigro JM, Lin D, Jenkins RB, Feuerstein BG, Burger C, Tihan T. Glial neoplasm resembling oligodendrogliomas in children: Does pediatric oligodendroglioma exist? Glioma marker network study. J Neuropathol Exp Neurol. 2003; 65:571 (Abstract).

4. Kreiger PA, Okada Y, Simon S, Rorke LB, Louis DN, Golden JA. Losses of chromosomes $1 \mathrm{p}$ and $19 \mathrm{q}$ are rare in pediatric oligodendrogliomas. Acta Neuropathol. 2005; 109: 387-92.

5. Preusser M, Hoischen A, Novak K, Czech T, Prayer D, Hainfellner JA, Baumgartner C, Woermann FG, Tuxhorn IE, Pannek HW, Bergmann M, Radlwimmer B, Villagrán R, Weber RG, Hans VH. Angiocentric glioma: Report of clinico-pathologic and genetic findings in 8 cases. Am J Surg Pathol. 2007; 31:1709-18.

6. Wang M, Tihan T, Rojiani AM, Bodhireddy SR, Prayson RA, Iacuone JJ, Alles AJ, Donahue DJ, Hessler RB, Kim JH, Haas M, Rosenblum MK, Burger PC. Monomorphous angiocentric glioma: a distinctive epileptogenic neoplasm with features of infiltrating astrocytoma and ependymoma. J Neuropathol Exp Neurol. 2005; 64:875-81.
7. Fuller GN. The WHO Classification of Tumours of the Central Nervous System, 4th edition. Arch Pathol Lab Med. 2008;132:906

8. Marburger T, Prayson R. Angiocentric glioma: A clinicopathologic review of 5 tumors with identification of associated cortical dysplasia. Arch Pathol Lab Med. 2011; 135:1037-41.

9. Lellouch-Tubiana A, Boddaert N, Bourgeois M, Fohlen M, Jouvet A, Delalande O, Seidenwurm D, Brunelle F, Sainte-Rose C. Angiocentric neuroepithelial tumor (ANET): A new epilepsyrelated clinicopathological entity with distinctive MRI. Brain Pathol. 2005; 15:281-6.

10. Geha S, Pallud J, Junier MP, Devaux B, Leonard N, Chassoux F, Chneiweiss H, Daumas-Duport C, Varlet P. NG2+/Olig2+ cells are the major cycle-related cell population of the adult human normal brain. Brain Pathol. 2010; 20:399-411.

11. Baisden BL, Brat DJ, Melhem ER, Rosenblum MK, King AP, Burger PC. Dysembryoplastic neuroepithelial tumor-like neoplasm of the septum pellucidum: A lesion often misdiagnosed as glioma: Report of 10 cases. Am J Surg Pathol. 2001; 25:494-9.

12. Dimou L, Simon C, Kirchhoff F, Takebayashi H, Götz M. Progeny of Olig2-expressing progenitors in the gray and white matter of the adult mouse cerebral cortex. J Neurosci. 2008; 28:10434-42.

13. Burger PC. What is an oligodendroglioma? Brain Pathol. 2002; 12:257-9.

14. Zhang J, Wu G, Miller CP, Tatevossian RG, Dalton JD, Tang B, Orisme W, Punchihewa C, Parker M, Qaddoumi I, Boop FA, Lu C, Kandoth C, Ding L, Lee R, Huether R, Chen X, Hedlund E, Nagahawatte P, Rusch M, Boggs K, Cheng J, Becksfort J, Ma J, Song G, Li Y, Wei L, Wang J, Shurtleff S, Easton J, Zhao D, Fulton RS, Fulton LL, Dooling DJ, Vadodaria B, Mulder HL, Tang C, Ochoa K, Mullighan CG, Gajjar A, Kriwacki R, Sheer D, Gilbertson RJ, Mardis ER, Wilson RK, Downing JR, Baker SJ, Ellison DW; St. Jude Children's Research Hospital-Washington University Pediatric Cancer Genome Project. Whole-genome sequencing identifies genetic alterations in pediatric low-grade gliomas. Nature Genetics. 2013; 45:602-12. 